\title{
Chapter 17 \\ Nurturing Collaborative Networks of Mobile Learning Researchers and Practitioners
}

\author{
Thomas Cochrane \\ Centre for Learning and Teaching (CfLAT), Auckland University of Technology, Auckland, New \\ Zealand \\ Vickel Narayan \\ Centre for Learning and Teaching (CfLAT), Auckland University of Technology, Auckland, New \\ Zealand
}

\begin{abstract}
In this article, we present the development of a framework for supporting and facilitating collaborative networks of reflective practice using mobile social media. Developed throughout a two-year collaborative mobile learning project \#NPF14LMD, the framework has subsequently been used to support two wider international networks of mobile learning researchers and practitioners. The \#NPF14LMD project was a national project comprised of three universities and three polytechnics across New Zealand. One of the goals of the \#NPF14LMD project was to create a collaborative network of practice across the six institutions participating in the project. The network provided a support and communication structure linking the six institutional communities of practice, enabling sharing of their experiences and a sense of belonging to a wider national and international community. This article outlines the use of mobile social media to facilitate the \#NPF14LMD network, and the subsequent application of this framework to support two international networks.
\end{abstract}

\section{INTRODUCTION}

Scaling and supporting mobile learning initiatives beyond individual practitioners and localised case studies has been one of the key impediments to mainstream adoption of mobile learning in higher education (Parsons, 2014; Punie, 2013). The lessons learnt from the several large scale mobile learning projects have had limited long-term impact on mainstream teaching and learning environments (Traxler, 2016a,

DOI: $10.4018 / 978-1-7998-7294-8 . c h 017$

Copyright $\odot$ 2021, IGI Global. Copying or distributing in print or electronic forms without written permission of IGI Global is prohibited. 
2016b). Mainstream adoption of mobile learning informed by the lessons learnt from the last 16 years of research and practice is hampered by an ever-increasing rate of technological change. However, we believe that one of the keys to support the integration of mobile learning across mainstream education is the need for practical frameworks to support collaboration between mobile learning researchers and practitioners (Laurillard, 2007, 2012), and technology stewards (Cochrane, 2014; Wenger, White, \& Smith, 2009). Such frameworks will support the exploration of mobile learning to facilitate new pedagogical strategies within a wide variety of educational contexts. Alongside the development of mobile devices has been the rapid development of social networks and social publishing platforms that are increasingly designed around mobile devices to facilitate sharing and show casing of user-generated content and user-generated contexts. As Cook and Santos (2016) argue, this confluence of mobile devices and social networks leads to three elements of state of the art mobile learning:

1. The ability to use social media and apps to enable new patterns of connected social, learning and work-based practices.

2. Design research allows us to engage in inquiry surrounding the transformative possibilities for $\mathrm{m}$-learning. Particularly, designing for ' $m$-learning' at scale is a big challenge.

3. Participants in new mass communications are now actively engaged in generating their own content and contexts for learning. (Cook \& Santos, 2016, p. 3)

Reeves (2015) makes the case that establishing "consortia of collaborating researchers, practitioners, and funding agencies focused on the most salient problems facing education may realise much greater impact" (Reeves, 2015, p. 618). The mobile learning research community in New Zealand is small (Cochrane, 2013; Cochrane, Narayan, \& Oldfield, 2015), with researchers and practitioners spread across the country and across institutions, leading to discussions in 2013 around the potential of establishing a national community of practice of mobile learning researchers and practitioners. Thus, we explored establishing a network to support best practice in mobile learning. These were some of the key drivers behind the establishment of the \#NPF14LMD project.

The National Project Fund 2014 Learners and Mobile Devices (\#NPF14LMD) project was the largest scale mobile learning in higher education project undertaken at a national level in New Zealand to date (Frielick et al., 2014). The \#NPF14LMD project drew upon the authors' experiences of reimaging professional development as communities of practice (Cochrane, Black, Lee, Narayan, \& Verswijvelen, 2012; Cochrane \& Narayan, 2012; Cochrane, Narayan, \& Oldfield, 2013), and the wider literature surrounding establishing and nurturing collaborative networks and communities of practice (Jameson, 2011; Learning and Skills Network, 2009; Wenger, McDermott, \& Snyder, 2002; Wenger et al., 2009; Wenger, White, Smith, \& Rowe, 2005). The development of supporting communities of practice (COP) was identified as a critical success factor for transforming pedagogy via mobile social media (Cochrane, 2014), and thus the project was initially framed around creating a network of COPs from six tertiary education institutions across the country. The project encompassed 54 researcher practitioners and over 1000 students across New Zealand over the period 2014-2015.

The \#NPF14LMD project was predicated upon the growing ubiquity of mobile device ownership, forecasted in International Telecommunications Union statistics (2014). In 2015 undergraduate student ownership of smartphones (92\%) exceeded student ownership of laptops (91\%) (Dahlstrom, Brooks, Grajek, \& Reeves, 2015). These statistics were confirmed for the New Zealand context through the \#NPF14LMD project student survey completed in 2015 (Frielick \& Whitehead, 2017). Participation in 
the \#NPF14LMD project involved lecturers integrating the use of mobile social media within the courses they were teaching over 3 semesters in 2014 through to the end of 2015. Participants were encouraged to ground their mobile learning project designs on relevant learning theory. Key learning theories and frameworks that informed the project design included, but were not limited to: connectivism (Siemens, 2004), social constructivism (Head \& Dakers, 2005; Vygotsky, 1978), rhizomatic learning (Cormier, 2008), the conversational framework (Laurillard, 2007), authentic learning (Herrington, Reeves, \& Oliver, 2009), constructive alignment (Biggs, 2003), heutagogy (Hase \& Kenyon, 2007; Luckin et al., 2010), and three levels of creativity (Sternberg, Kaufman, \& Pretz, 2002). The relevance of these learning theories to the \#NPF14LMD project network design are explored further in section 3 of this paper. The project was grounded upon the wide body of research literature surrounding mobile learning, and involved the compilation and sharing of a categorized custom literature review (Aguayo, Cochrane, \& Narayan, 2017). We drew upon the work of leading mobile learning researchers such as: Sharples et al., (2007) - connecting mobile learning practice to learning theories, Traxler (2010) - focusing upon BYOD approaches, Cook (2009) - exploring the mobility of the learner, Pachler et al., (2010) - exploring the socio-cultural impact of mobile learning, and Kukulska-Hulme (2010) - exploring mobile learning as a catalyst for new pedagogies.

Throughout the development of the project participants were encouraged to explore the unique affordances of mobile devices to enable innovative pedagogical strategies within their own discipline contexts. We agree with Bannan, Cook and Pachler (2015) that "The nature of learning is being augmented and accelerated by new digital tools and media, particularly by mobile devices and the networks and structures to which they connect people" (Bannan et al., 2015, p. 1). Bannan, Cook and Pachler (2015) highlight eight mobile device affordances, to which we provide examples of the types of applications the project participants were encouraged to explore:

- $\quad$ Collaborative and communicative potential; for example, Twitter, Skype

- Interactivity and nonlinearity; for example, Google Now, Virtual Reality

- $\quad$ Distributed knowledge construction; for example, Google Plus, Google Docs

- Multimodal knowledge representation; for example, YouTube, Vine, Vyclone

- Authentic/contextualized/situated material, interaction, tasks and settings; for example, Augmented Reality

- Multi-functionality and convergence; for example, speech recognition such as Siri

- Portability, ubiquity, personal ownership: for example, Smartphones

- User-generated content and contexts: for example, ePortfolios such as Behance

As the project was a collaborative network of diverse communities of practice, mobile social media was used to facilitate collaboration and communication, and curate user-generated content. Thus, informed by Cormier's concept of rhizomatic learning the project coordinators focused upon designing triggering events throughout the life-span of the project to generate participant discussion and sharing of practice between the project COPs. 


\section{METHODOLOGY}

Our project aimed to create a collaborative partnership between tertiary researchers and practitioners in several Polytechnics and Universities throughout New Zealand, establishing a network of communities of practice (COP) sharing their experiences of exploring the potential of mobile learning within their own local discipline contexts. The project was co-funded by AKO Aotearoa and the participating institutions, with a combined budget of $\$ 300000 \mathrm{NZ}$ over two years. The project was predominantly practice-based aiming to inform improved student learning outcomes.

\subsection{Research Questions}

Two overall project research questions formed the basis for the foundational concepts underlying the \#NPF14LMD collaborative network.

- RQ1: Will learners' mobile devices deliver innovation, inclusion, and transformation - the main potential benefits for learners? If so, how?

- RQ2: What is the 'framework for enhanced learning and institutional change' that will deliver these benefits?

\subsubsection{Research Question 1}

The mobile learning research literature indicates that innovation (Kukulska-Hulme, Sharples, Milrad, Arnedillo-Sanchez, \& Vavoula, 2009; Parsons, 2013), inclusion (Attewell, Savill-Smith, \& Douch, 2009; Traxler, 2010), and transformation (Lindsay, 2015; Pachler et al., 2010; Puentedura, 2006) are key benefits of mobile learning. The network was designed to allow sharing of practice that explored these benefits from a variety of contexts and approaches. Sharples (2013) summarises the range of approaches taken by mobile learning initiatives as a scale from enhancing curriculum-led classrooms to informal highly mobile learning environments (Figure 1), and the \#NPF14LMD projects encompassed this range (\#NPF14LMD, 2017d).

Figure 1. Mobile learning dimensions from classroom-led to informal highly mobile, based on (Sharples, 2013, p. 6)

\begin{tabular}{|c|c|c|c|c|c|}
\hline $\begin{array}{l}\text { Handheld } \\
\text { response } \\
\text { systems }\end{array}$ & $\begin{array}{l}\text { PDAs in } \\
\text { classrooms }\end{array}$ & $\begin{array}{l}\text { Mobile } \\
\text { technology } \\
\text { for field trips }\end{array}$ & $\begin{array}{l}\text { Handheld } \\
\text { tourist guides }\end{array}$ & $\begin{array}{l}\text { Social } \\
\text { networking } \\
\text { and media } \\
\text { creation on } \\
\text { smartphones }\end{array}$ & $\begin{array}{l}\text { Informal } \\
\text { collaboration } \\
\text { with mobile } \\
\text { phones }\end{array}$ \\
\hline
\end{tabular}

Fixed setting, curriculum led

Mobile, informal 
Cook and Santos (2016) describe three aspects of state of the art mobile learning research: (1) the ability to use social media and apps to enable new patterns of connected, social, learning and workbased practices; (2) design research around the transformative possibilities of mobile learning; (3) a focus upon user/learner generated content and contexts. Basing the \#NPF14LMD collaborative network around the use of mobile social media was one way to approach innovation (facilitate new pedagogies), inclusion (facilitate open access to all participants), and transformation (from the social use of mobile social media to the educational use).

\subsubsection{Research Question 2}

The collaborative network was developed as part of a model framework for practice and institutional change that we envisioned that the project practitioners might apply within their own contexts. Facilitating lecturer professional development and providing a supporting technological infrastructure were core elements of the framework. We borrowed concepts from Puentedura's (2006) educational technology adoption framework (SAMR - Substitution, Augmentation, Modification, Redefinition), and all the participating researchers and practitioners were supplied with an iPad mini and an iPhone each to personalise and facilitate access to the use of mobile social media in their own contexts. We did not remotely manage or image participants' devices as we wanted to simulate a BYOD (Bring Your Own Device) environment. Jameson et al., (Jameson, Ferrell, Kelly, Walker, \& Ryan, 2006) emphasise the critical nature of developing trust within networks and communities. Building trust within a new collaborative network of researchers and practitioners who did not know all the other participants was a key goal of the use of social media within the \#NPF14LMD network.

The research sub-question related to both the two main project research questions that this paper explores is: How can we use mobile social media to facilitate and sustain the \#NPF14LMD network?

\subsection{Participants}

The selection of project participants was a three-stage process. The first stage involved the invitation of project local coordinators from the six institutions by the project co-leader. Potential participants were identified by their previous experience of mobile learning research and practice within the New Zealand tertiary education sector. Participants who accepted the invitation to participate then gained institutional approval to sign the collaborative project fund application. Upon acceptance of the project proposal by the national funding body (AKO Aotearoa) the second stage involved the invitation of local practitioners (lecturers) from each institution to participate in the project by the local coordinators. All the project coordinators and local practitioners were then supplied with an iPhone 5S and an iPad mini2. The final participant selection stage involved the local practitioners inviting their own students to participate in the project through implementing the integration of mobile learning in their courses. Students used their own devices (BYOD) when participating in the project. Ethics consent for the participating lecturers was approved through the lead institutions ethics committee consent process. Each institution was responsible for acquiring local ethics consent for the participating students. The project participants were drawn from a wide range of discipline contexts, including: Paramedicine, Game development, Public Health, Communication Studies, Occupational Health, Performance for Screen, Computing, Pre-service Teacher Education, Carpentry, Business, Zoology, and Early Child Care Education. Two of the project COPs were based within a single discipline, while four COPs were interdisciplinary. This gave the project a wide base of participant experiences. 


\section{3. \#NPF14LMD NETWORK FORMATION}

The \#NPF14LMD project spanned two years from 2014 to 2015. The timeline of the key milestones around the formation and development of the collaborative network was across four main phases:

1. Formation of the collaborative network

a. October 2013: Initial expression of interest with invited coordinators from the 6 institutions

b. December 2013: Acceptance of project proposal for AKO Aotearoa funding

c. February 2014: Initial meeting of project coordinators and administration team

d. February 2014: Mobile social media Ecology Of Resources introduced (Google Plus, Twitter...)

e. May 2014: Local COPs established at each institution

2. Initiating the implementation of the collaborative network

a. $\quad$ August 2014: First iteration of mobile social media projects in practitioners courses

b. September 2014: Webinar series introduced

c. November 2014: Sharing of project progress with the MINA2014 and Ascilite2014 conferences

3. Maturing of the collaborative network

a. March 2015: Project coordinator roadshow - meeting with all local COPs

b. March 2015: Launch of the Mobile Social Media Learning Technologies cMOOC (Mosomelt) as an optional COP support framework (Cochrane, Narayan, \& Burcio-Martin, 2015; Cochrane, Narayan, Burcio-Martin, Lees, \& Diesfeld, 2015)

c. March 2015: Second iteration of integrating mobile social media in practitioner courses

4. Sharing of practice from the network of case studies

a. July 2015: Virtual Symposium

b. July 2015: ISATT2015 Conference

c. August 2015: Third iteration of integrating mobile social media in practitioner courses

5. Dissemination of project progress and outcomes

a. November2015: TERNZ2015 Conference

b. November2015: MINA2015 Conference

c. December2015: Ascilite2015 Conference

d. February 2016: Wrap-up of \#NPF14LMD project and release of final project report published

A key strategy was to model the use of the mobile social media tools we were exploring throughout the project, and create an environment that could facilitate sharing of ideas and practice across the geographically disperse participants. We based the design of the \#NPF14LMD social network around the concepts of social constructivism (Vygotsky, 1978), nurturing communities of practice (Wenger, 1998; Wenger et al., 2002; Wenger et al., 2009), connectivism (Siemens, 2004), and rhizomatic learning (Cormier, 2008). The \#NPF14LMD network connected teams of researchers and practitioners across six institutions nationally. Cormier's concept of rhizomatic learning decentralises learning environments and refocuses the role of the teacher from deliverer of content to a designer of an ecology of resources and triggering events that enable learner discussion and creativity. Drawing upon Luckin's (Luckin, 2008) concept of a learner centred ecology of resources and Pachler, Bachmair and Cook's (2010) socio-cultural ecological concept, Cook et al., (2013) argue that mobile social media can bridge the socio-cultural milieus of everyday life and education, and thus we based our ecology of resources upon 
a collage of mobile social media. The choices of the elements of this collage of mobile social media was based upon what we believed to be best practice at the time of the development of the project. Each element of the ecology of resources was chosen based upon its ability to integrate within and support our core network activities. Each element of the ecology of resources enables sharing and collaboration of user-generated content, forming a sustainable ecosystem to facilitate and nurture the collaborative network with minimum external technology support required. Through the implementation of this ecology of resources we attempted to model the concepts of social constructivism, nurturing communities of practice through connectivism and rhizomatic learning within the \#NPF14LMD collaborative network. There were six main elements that emerged within an ecology of resources to support the project: (1) a community-driven hub and discussion forum (connectivism), (2) collaboration and communication channels (social constructivism), (3) opportunities for sharing practice (rhizomatic learning), (4) a way of linking the local communities of practice into the wider network (brokering communities of practice), (5) a repository for project documentation (drawing upon the principles of constructive alignment), and

(6) building a BYOD infrastructure strategy (enabling all elements of the collaborative network). An ecology of resources was developed consisting of a core suite of mobile social media tools including:

1. Community Hub

a. A Google Plus Community with 60 members http://bit.ly/1zP2S0T

b. A social media hashtag \#NPF14LMD

c. A collaborative participant Google Map

2. Collaboration

a. Twitter - generating a network of 126 users and almost 700 conversations

3. Sharing Practice

a. Google Plus Hangouts

b. A series of open access Webinars broadcast live and archived on YouTube (http://bit. ly/1IAJRKWv)

4. Supporting Local COPs

a. ePortfolios

b. Face to face weekly meetings

5. Project Documentation

a. A Google Drive folder of project documents

6. BYOD Infrastructure

a. Participating practitioners were supplied with an iPad Mini and an iPhone 5S as personal devices

Other key collaboration strategies included participation in presenting at a variety of symposia and conferences across New Zealand and Australia (Cochrane, Frielick, et al., 2015; Cochrane et al., 2014; Frielick, Cochrane, Narayan, Moyle, \& Oldfield, 2015; Heap et al., 2015). Participation in these symposia and conferences also served to generate a broader network of interest in the project and conversations on social media that linked a global network of interested followers of the project. Figure 2 illustrates the \#NPF14LMD project ecology of resources (EOR). 
Figure 2. \#NPF14LMD project ecology of resources

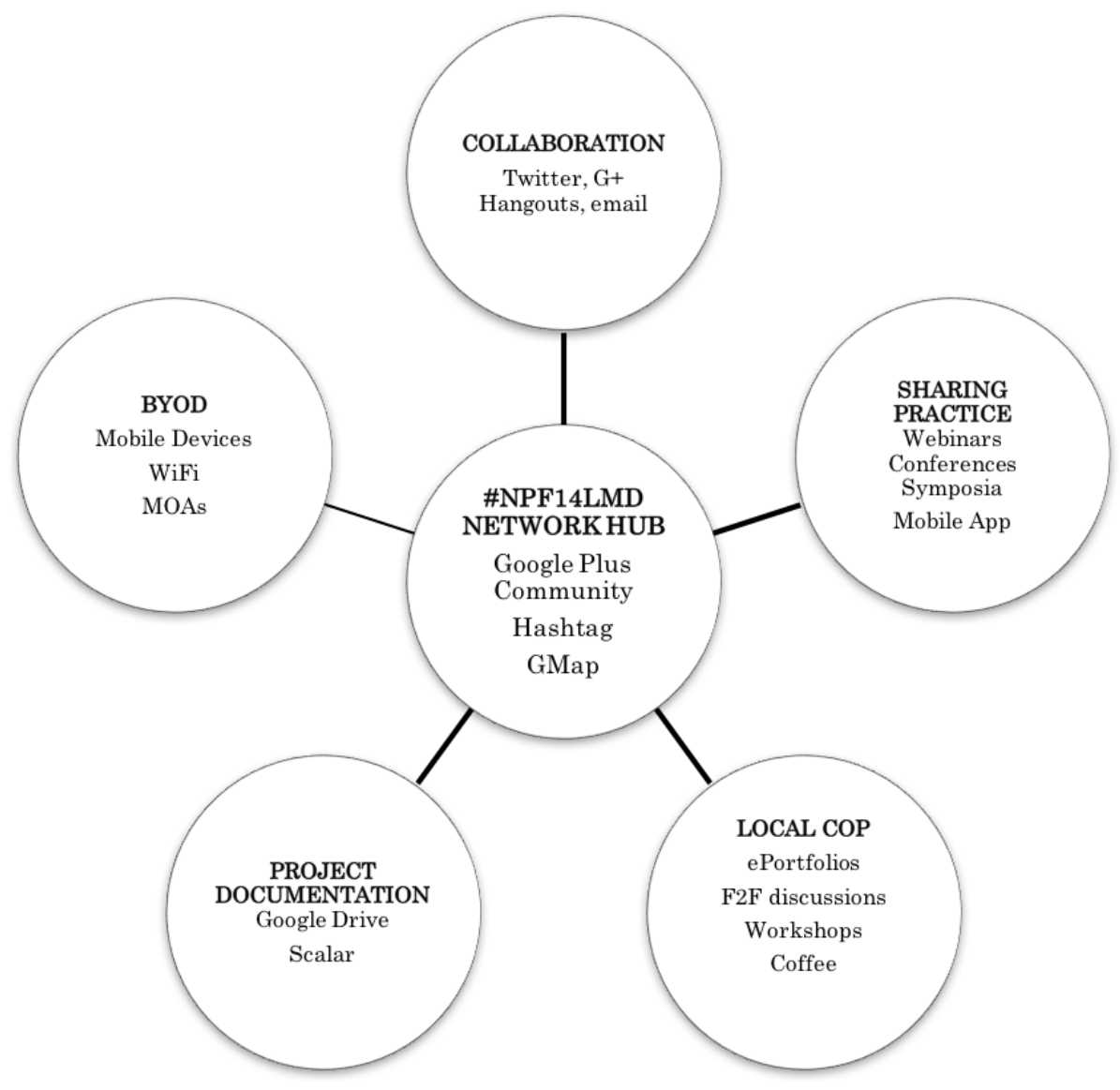

\section{Analysing the \#NPF14LMD Collaborative Network}

In this section we analyse the \#NPF14LMD project through exploring the six core elements of our ecology of resources (EOR) framework: establishing a network hub, collaboration, sharing practice, facilitating local COPs, collaborative project documentation, and enabling this EOR through a BYOD strategy.

\subsection{Establishing a Network Hub}

The design of the NPF14LMD network was built upon principles from Connectivism (Siemens, 2004): this involved linking a national network within a global network of mobile learning researchers and practitioners. One of the core goals of the collaborative network was to explore how mobile devices and social media could enable and facilitate new pedagogies such as Heutagogy (Hase \& Kenyon, 2007; Luckin et al., 2010): that focuses upon building learner capacity rather than merely competence through a focus upon supporting learner self-determination and negotiation of the learning environment and outcomes. Thus the \#NPF14LMD project network EOR provided multiple channels for sharing and collaboration, including an email list serve. This ecology of resources provided participants with several options for 
collaboration to choose from, with the Google Plus Community serving as a central hub from which to find the various project resources and collaboration channels and was a core means of brokering the practice of each individual community of practice within the network (Figure 3).

Figure 3. Screenshot of \#NPF14LMD Google Plus Community

\begin{tabular}{|c|c|c|}
\hline iPad $₹$ & $\begin{array}{c}\text { 3:54 PM } \\
\text { a plus.google.com }\end{array}$ & $4 * 89 \%$ \\
\hline$\equiv$ & NPF14LMD - Learners and Mobile Devices & +8 \\
\hline
\end{tabular}

60 members - Public

\section{NPF14LMD - Learners and Mobile Devices}

Ako Aotearoa National Fund Project - Learners and mobile devices

About Community

This is a community page for all members of the Ako Aotearoa National Fund project on Learners and mobile devices.

http://akoaotearoa.ac.nz/learner-mobile-devices

(5) Tags Explorer Twitter analysis

G Twitter Google Map

*t TAGBoard

G Participant Map

(8) Project Blog

Q QR Code

- AKO Aotearoa NPF Website

D Webinar Archive

$G$ Documents: Shared Google Drive Folder

G Webinar Schedule (WIP)

Г All posts

4. What do you want to share?

ㅁ

Thom Cochrane Owner , Reports $v$

$29 \mathrm{w}$

Learners and Mobile Devices project report now available on App Store https://appsto.re/nz/Vqcaib.i 
The ability to create calendar events and schedule reminders for upcoming events such as webinars within the G+Community was very useful for helping to coordinate interaction within the network of the project. Because we wanted to model open practice and allow for project interaction from a potentially global community of mobile learning experts we decided to make all the project social media platforms public, but contribution was by invitation only. The email list serve and project documentation folder were kept closed to the participants only for more private sharing within the network. Within the first three months of establishing the project there were over 80 posts on the Google Plus Community, with 35 comments on these posts, and 44 \#NPF14LMD Twitter hashtag users active creating 182 tweets. In July 2015 we convened a virtual symposium (http://bit.ly/1SSxSup), whereby project participants collaboratively created a map of their local project locations across New Zealand, and embedded project presentations and reflective VODCasts into this map (http://goo.gl/maps/c09S0). The map was arranged as several layers, including a layer for the project coordinators, and a layer for each participating institution. There were 39 contributors to the collaborative project map, with 32 videos embedded within it, creating a geolocated multimedia overview of the various educational contexts explored throughout the project. Created and shared in July 2015 the \#NPF14LMD participant Map had 534 views between July 2015 and December 2015.

\subsection{Collaboration}

We attempted to embed a culture of collaboration within the \#NPF14LMD project network based upon social constructivism (Head \& Dakers, 2005; Vygotsky, 1978): for example, basing the wider project around collaborative curriculum design within each individual COP, and learner-generated team projects rather than a pre-determined template or particular format. One of the core tools within our EOR used to support collaboration was the use of Twitter. The project coordinators, as the more experienced peers, modelled the use of Twitter to create a professional network for the project participants.

Twitter interactions using the \#NPF14LMD project hashtag were graphically analysed via TAGSExplorer (Hawksey, 2011). TAGSExplorer utilizes a Twitter hashtag search to tabulate a Google Spreadsheet from which various data analysis functions are automated, with the data available at http://bit. ly/1OQkB2s and an initial network diagram screenshot as at February 2014 shown in Figure 4. In Figure 4 TAGSExplorer analysis represents individual Twitter users as individual nodes, with conversations between the individuals represented by dashed lines for mentions, and retweets represented as solid lines.

The density of twitter conversational interaction is shown by the visualisation of Twitter replies, mentions and retweets that is illustrated as a growing network of conversations recorded in a time-lapse video https://youtu.be/XFeKrAXbgIA. The time-lapse video illustrates the growth of the Twitter network around the project, highlighting that the network grew in reach and confidence around specific critical incidents such as conferences and symposia where project participants shared their experiences and practice. Twitter was also a key tool to nurture the network - as practitioners joined Twitter (mostly for the first time as a result of the project) they were welcomed into the network, and peer feedback was given through likes and retweets of ideas and practice shared via the Twitter hashtag. A snapshot of the TAGSExplorer visualization after almost two years of the project (December 2015) is shown as a cumulative network diagram in Figure 5, where the largest nodes are the most prolific twitter conversationalists using the project hashtag \#NPF14LMD. Figure 5 shows the growth of the \#NPF14LMD project user network over the two years of the project, from an initial 12 core users (Figure 4) to 122, and 182 conversations (Figure 5) to 662. 
Figure 4. \#NPF14LMD project TAGSExplorer analysis February 2014

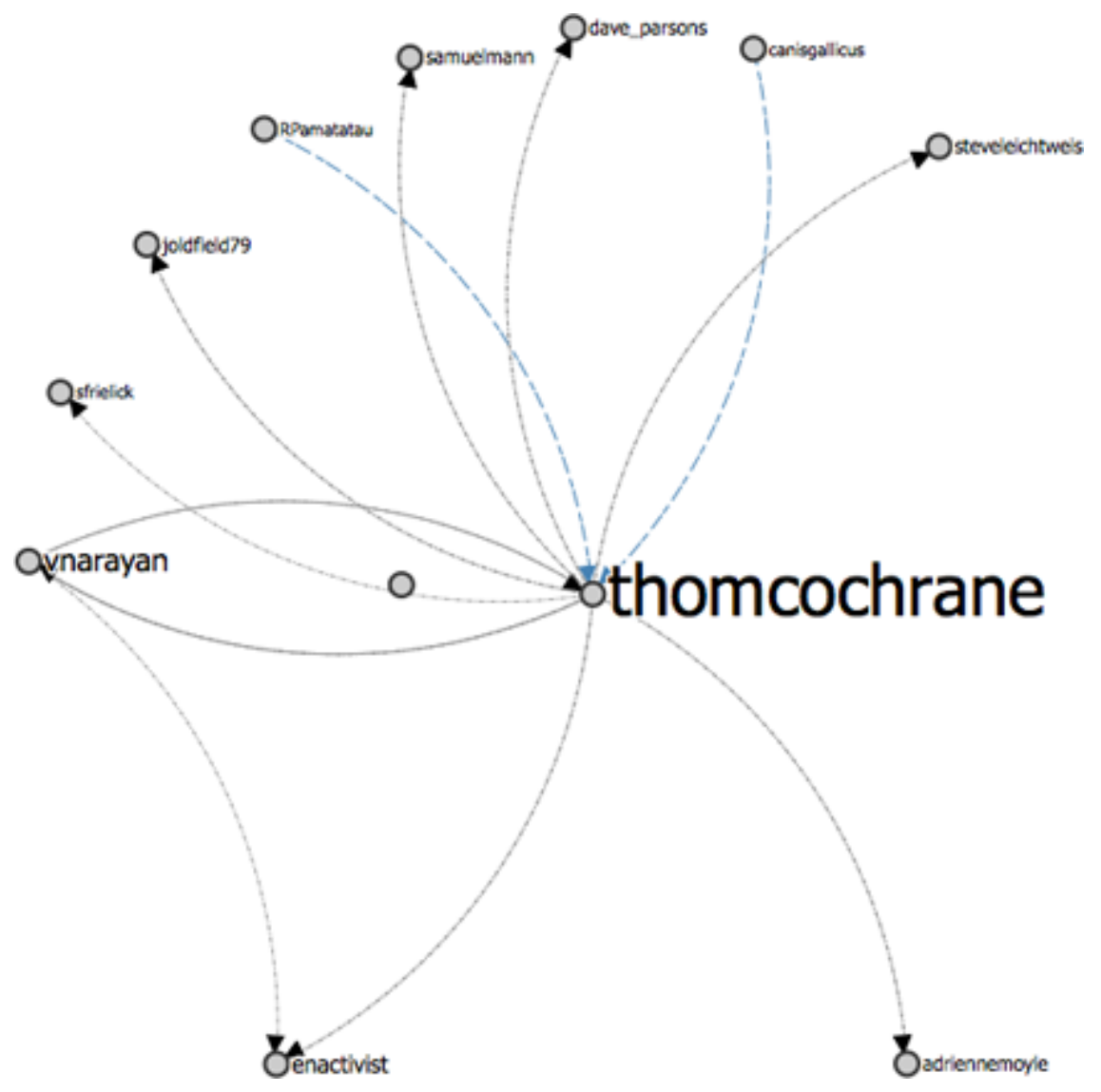

Analysis of the key network nodes indicated by TAGSExplorer shows that the top Twitter conversationalists for the project include not only the project coordinators, but also several practitioners within the top 20. The project leaders featured prominently through modeling the use of Twitter throughout the project, encouraging and generating conversations around the project activities and sharing resources between the six project teams.

\subsection{Sharing Practice}

We attempted to model the network activity around shared participant practice based upon the principles of rhizomatic learning (Cormier, 2008): for example, utilising a decentralized structure and designing the network activities around 'triggering events' to facilitate participant discussion and sharing. These triggering events were responsive to participant needs and their projects throughout the overall project, and arose out of weekly discussions among the project coordinators via regular video conferences.

The Google Plus Community formed a hub for linking the shared mobile social media EOR activity around the project. The use of the Google Plus Community was optional for the project participants although all participants were encouraged to contribute at some level. Significant activities included a weekly project coordinators video Hangout (for example: http://bit.ly/20zcErm), a series of webinars with 
Figure 5. \#NPF14LMD project TAGSExplorer analysis December 2015

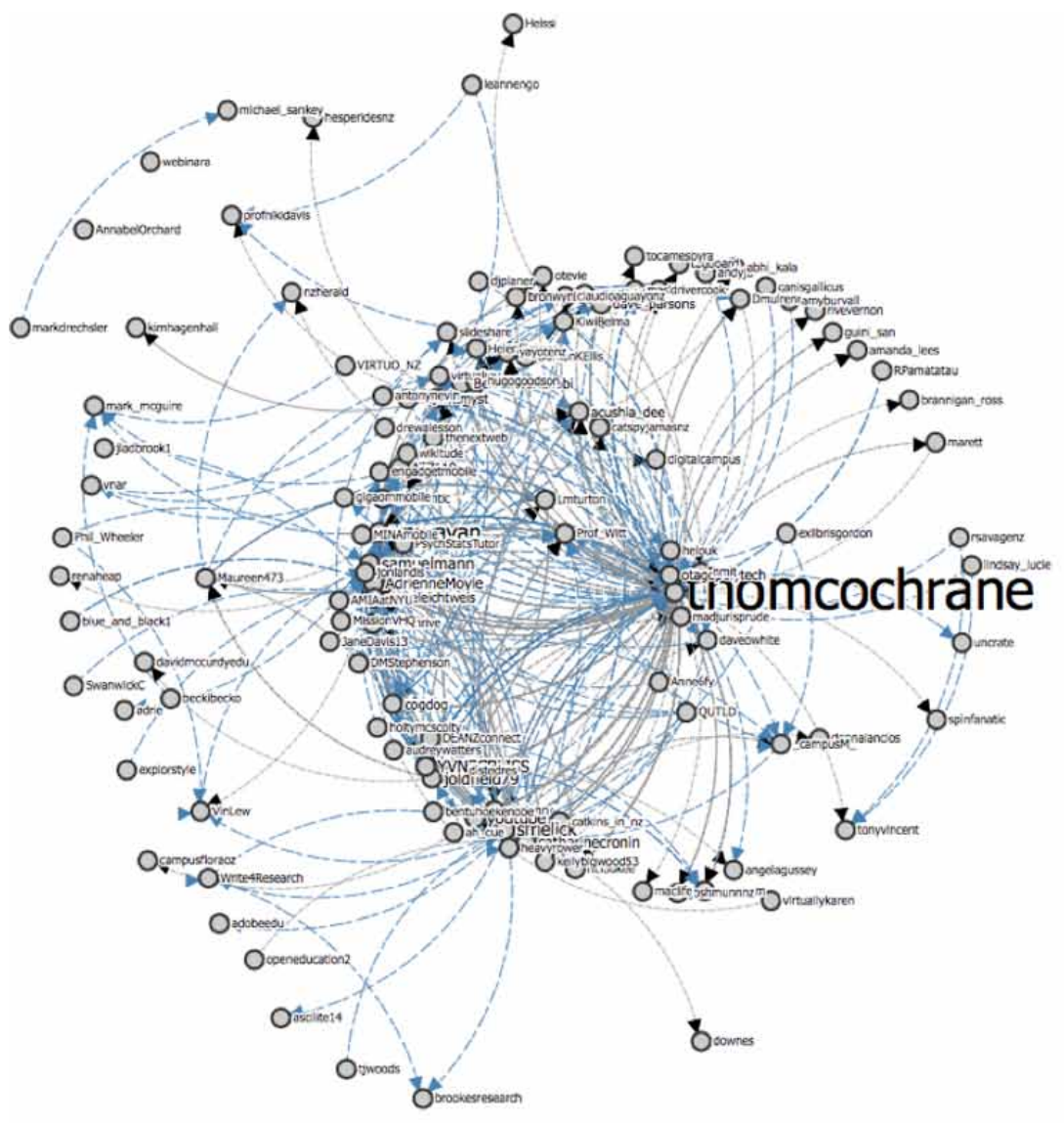

126 nodes 662 edges I

invited guests, a series of project report webinars, a virtual symposium, shared links to project resources and research, and sharing of presentations at six conference during the project, collated in Table 1.

The global reach of the project is illustrated by a map of Twitter geotagged tweets (http://bit. ly/1Qbjn5b), shown in Figure 6, with tweets originating predominantly from New Zealand, Australia, the United Kingdom, USA and Canada.

\subsection{Collaborative Project Documentation}

Biggs (2003) concept of constructive alignment guided our design of collaborative project documentation: for example, aligning the design of the network activities with the goal of modeling the educational 
Nurturing Collaborative Networks of Mobile Learning Researchers and Practitioners

Table 1. Summary of \#NPF14LMD project sharing of practice activity

\begin{tabular}{|l|l|}
\hline Webinars http://bit.ly/1IAJRKW & 13 Live streamed and archived videos \\
\hline Collaborative Google Map participants http://goo.gl/maps/c09S0 & 39 participants, 32 embedded videos \\
\hline MINA2014 Conference Twitter activity & http://bit.ly/1mjDAIW \\
\hline Ascilite2014 Conference Twitter activity & http://bit.ly/1PGrTI8 \\
\hline 2015 Roadshow G+ Photos & http://bit.ly/1KwFYHP \\
\hline ISAAT2015 Conference Videostar & http://bit.ly/1VY1J45 \\
\hline TERNZ2015 Conference Twitter activity & http://bit.ly/1L59CPd \\
\hline Ascilite2015 Conference Twitter activity & http://bit.ly/1oeQb1E \\
\hline
\end{tabular}

use of mobile social media. A collaborative Google Doc was used to create the Webinar and project report schedules (http://bit.ly/1K4eGsh), these were live-streamed as Hangouts On Air for synchronous participation, and archived on YouTube for asynchronous viewing. The webinar series topics included:

- Collaborative mobile film production

- The affordances of the open web

- $\quad$ Being an open educator

- Qualitative research approaches

- A journey from skeptic to digital ninja

- Maori learners and pedagogies

- Mobile pedagogies

The series of mid-2015 project report Hangouts were collated in a YouTube playlist.

\subsection{Facilitating local COPs}

We leveraged Wenger et als., (2009) concept of technology stewardship to guide the facilitation of the local COPs. The activity of these COPs was focused upon the context of higher education through exploring the concepts of the Conversational framework (Laurillard, 2001, 2007): for example, encouraging discussion between learners and more expert peers, and Authentic learning (Herrington et al., 2009): for example, designing project shared activities around real world pragmatic scenarios.

Two examples of the discipline based case studies within the \#NPF14LMD project network include the use of mobile technologies within a performance for screen course (Brannigan, Walsh, Graham, \& Cochrane, 2015), and the integration of mobile social media within a game development course (Kenobi \& Cochrane, 2015). The performance for screen case study explored the use of mobile screen mirroring displays within a live performance space to create new forms of interaction, and to enable students to rapidly record and critique one another's' performances using their mobile devices to capture the performance and then play back the performance for instant critique and evaluation via the large screen. This case study also explored the potential of mobile augmented reality to enhance live performances. The performance for screen students created individual Wordpress.com blogs as online journals of their learning and eportfolios, and their lecturers curated these blogs using the mobile application Flipboard on their iPads. In the game development case study MOAs were used for screen casting to model and 
Figure 6. Map of Twitter geotagged tweets for \#NPF14LMD

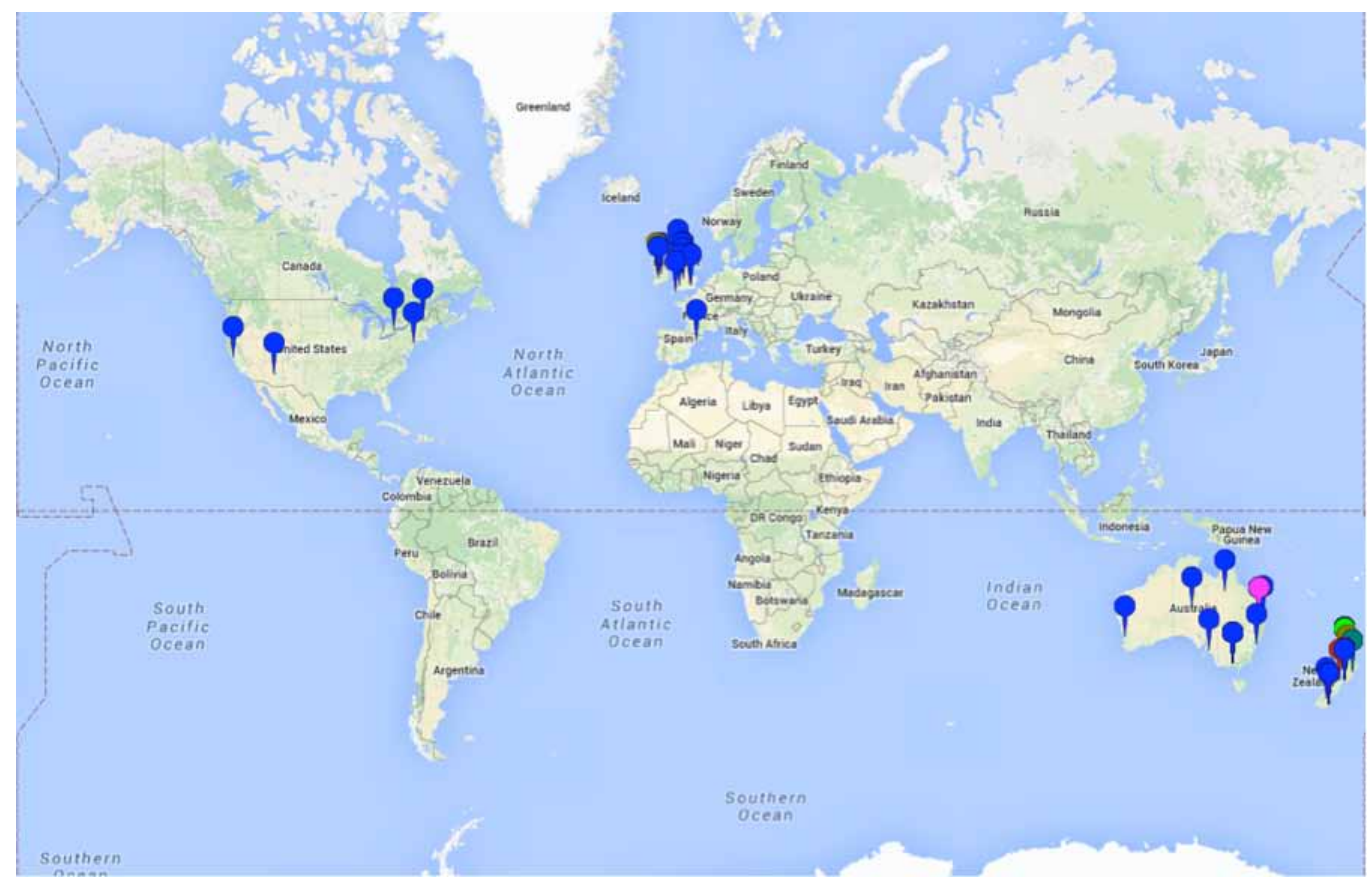

demonstrate game designs from students' laptops and mobile devices. Third year students modeled their design and development processes to first year students using these screen-mirroring technologies. The game design project also evaluated and implemented the use of social media project management apps (for example: Trello, Slack, and Basecamp) and Google Plus Communities to stream-line game development project timelines, goals, student team management, resource sharing, discussion forums, and lecturer feedback. The instant notification of updates and announcements via the mobile apps on their own devices facilitated a faster and more effective team environment.

\subsection{Enabling the EOR Through a BYOD Strategy}

A BYOD strategy enabled all elements of the collaborative network, including supporting Creativity (Kaufman \& Sternberg, 2007; Sternberg et al., 2002): for example, building upon the concept of three levels of creativity that move along a continuum from replication, incrementation, and reinitiation. This was aligned with the SAMR educational technology adoption model (Puentedura, 2006): where replication aligns with substitution and augmentation of current practice, incrementation aligns with modification of current practice, and re-initiation aligns with redefining the possibilities for new practices. This was achieved through supplying the participating educators with their own iPhone and iPad, and the development of large mobile screens to support the infrastructure of the projects by enabling the small personal screens of mobile devices to become collaborative group presentation tools via wireless screen mirroring. We nicknamed these custom designed screens MOAs: Mobile Airplay Screens (Cochrane \& Munn, 2016; Cochrane, Munn, \& Antonczak, 2013). The platforms chosen for our EOR were chosen to support multiple device platforms, and to be accessible via mobile Apps on a range of mobile devices. 


\section{DISCUSSION}

\subsection{Project Research Questions}

The focus of this paper is not upon answering the overall project research questions per se, rather the focus is on how the project network was nurtured and supported throughout its lifespan. The key findings of the project with respect to the research questions are summarized in various outputs (\#NPF14LMD, 2017b), including conference posters and symposia (\#NPF14LMD, 2017a), the project funding website summary (Frielick et al., 2014), and an interactive online report (\#NPF14LMD, 2017c) in which the key findings are summarized under two foci: for teachers, and institutions.

\subsubsection{Key Findings and Practical Strategies for Teachers}

1. Teachers should have access to the mobile devices that their learners do.

2. Teachers should have their technological and pedagogical development supported through a community of practice model.

3. Teachers should be empowered to experiment with new tools and not be afraid to fail

4. The mobile device should be approached as part of a shift in pedagogy and assessment where technology is integrated with good teaching practice and learning theory.

5. A close collaborative and inclusive learning environment enables teachers to work alongside learners with the implementation of mobile devices.

6. The use of mobile devices allows for engagement both inside and outside the classroom

\subsubsection{Key Findings and Recommendations for Institutions}

1. Teachers should have access to mobile devices that their learners do

2. There should be robust infrastructure to support current needs as well as encouraging innovation and experimentation with new technology and spaces

3. There should be a robust digital strategy that accounts for the needs of the implementation of mobile devices, access to mobile devices by learners and how users and considers values that are often overlooked in policy and strategy.

\subsection{Nurturing the Network}

The project participants were drawn from a wide variety of discipline contexts and represented a wide range of prior mobile learning experience. It took significant time for many project participants to gain confidence with using and interacting actively with the project social media EOR. One of the key initial barriers for many participants was the use of publically viewable social networks and protocols around the use of social media within educational contexts. For many participants, the project was their first foray into active participation on these social networks. A series of project roadshows in March 2015 at each participating institution was effective at mediating the concept of the mobile social media EOR supporting the network (http://bit.ly/1 KwFYHP). The introduction of a project email list serve was aimed at providing a foundational communication and discussion forum for the project participants, however it was only ever used as an announcement channel for project administration purposes. A core group of 
project coordinators and practitioners made regular active use of the mobile social media channels, while others lurked passively on the periphery of this core group, with some preferring to keep their project activity private to themselves and their students via institutionally managed systems such as Mahara and Moodle. However, as participant confidence with the educational use of mobile social media grew throughout the project we began to see several practitioners create their own versions of social media ecology of resources to support their students and classes. Each of these ecologies was made up of a unique blend of social media and institutional tools that were suitable for each context. The final online interactive project report contains many examples of practitioner reflections (\#NPF14LMD, 2017d). The project report evidences that participants theoretically grounded their use of mobile social media from a variety of learning theories and frameworks. These theoretical perspectives provided a rich foundation from which to build the educational use of mobile social media within the various curriculum contexts, described within the case studies covered by the final project online report.

There were different institutional and infrastructure barriers and enablers experienced within each institution, however working with the institutional IT support services to provide a robust wifi network for the project participants was a common theme. For example: there were many posts shared in the G+ Community with ideas and hints from the participants regarding ways of implementing wireless screen mirroring from mobile devices. While initially part of the project plan, the provision of MOAs: Mobile Airplay Screens (Cochrane, Munn, et al., 2013), for each institution exceeded the available project budget and were limited by the practicalities of supply and transportation to each institution, hence each institution explored their own wireless screen-mirroring solution.

The use of a common social media hashtag (\#npf14lmd) enabled a sense of connectivity and conversation between the geographically disperse six groups. Twitter and the Google Plus Community proved to be the key conversational curation points. Critical incidents in the use of social media to support the collaborative network included the development of the weekly webinar series, practitioner reports via Google Plus Hangouts, a virtual symposium with presentations linked via a collaborative Google Map, and collaborative presentations at several conferences throughout the project. Individual case studies and outcomes are available at http://mobilelearners.nz/.

The identification of issues surrounding practitioner awareness and adoption of mobile social media led to the development of the MOSOMELT cMOOC as an agile and flexible response to provide a framework for professional development (Cochrane \& Narayan, 2016; Cochrane, Narayan, \& Burcio-Martin, 2015). One of the limitations of the \#NP14LMD project approach was the relegation of the importance and potential impact of reflective practice informed by peer reviewed research, as the project funding body were primarily interested in generating practical evidence of improved outcomes for students, reified in innovative teaching practice. The development of the MOSOMELT cMOOC provided a practical opportunity to support both the sharing of teaching practice and the development of reflective research profiles and participation via encouraging participants to establish professional profiles on social research networks such as Researchgate, Academia.edu, and engage with Altmetrics (Cochrane, Narayan, \& Antonczak, 2015; Cochrane, Narayan, Antonczak, \& Burcio-Martin, 2016).

\section{FUTURE DIRECTIONS}

The \#NPF14LMD project is now completed, but the impact of the collaborative network that has resulted is ongoing. Many of the core \#NPF14LMD participants were invited to become members of 
the Ascilite mobile learning Special Interest Group (Australasian society for computers in learning in tertiary education mobile learning SIG), established in 2016. The Ascilite mobile learning SIG aims to bring together interested researchers and practitioners across the Australasia region and globally, to deepen our understanding of the impact and potential of mobile learning in higher education (https:// ascilitemlsig.wordpress.com/about/). The SIG focuses upon design-based research as a methodology, and heutagogy as a foundational pedagogy. Thus, the Ascilite mobile learning SIG links a broader range of participants within a specific mobile learning research interest. The Ascilite mobile learning SIG applies and refines many of the elements of the support framework developed out of the \#NPF14LMD project. The collaborative network support framework is also being used to support the development of further mobile learning research projects based around generalizing the Mosomelt cMOOC that was developed to support the \#NPF14LMD project. The CMALT (the Certified Member of the Association for Learning Technology) cMOOC project (https://www.researchgate.net/project/CMALT-cMOOCDeveloping-a-scalable-lecturer-professional-development-framework) links six national and three international institutions in developing cMOOCs for professional development.

\section{CONCLUSION}

In this paper, we have explored the impact of the use of a mobile social media EOR to facilitate and sustain the \#NPF14LMD network over the two years of the collaborative project. The use of mobile social media to support the \#NPF14LMD collaborative network enabled both active and passive participation as an opt-in form of facilitating sharing and collaboration throughout the two years of the project. Four of the six participating groups became regular contributors to the national collaborative network, while the other two groups lurked on the periphery of the network. A significant benefit of the use of social media to support the project network was the ability to create a global impact and awareness around the project and to link global experts in mobile learning into the network. This allowed the core members of the project to broker the activities and outcomes of the project to a wider global network through conference publications and presentations and the option of following or participating in the project via the project social media hashtag. Another significant benefit was the development of participants' confidence in becoming mobile social media users and the development of professional and educational practices that they could then model to their own students, and explore integrating into the curriculum. Via development of a cMOOC to support the professional development of the \#NPF14LMD project participants we have established a simple EOR framework that can be applied to supporting other collaborative networks of educational researchers and practitioners, inspired by Reeves' call for "expanding educational design research through the establishment of consortia of collaborating researchers, practitioners, and funding agencies focused on the most salient challenges faced in education today" (Reeves, 2015, p. 613).

\section{REFERENCES}

Aguayo, C., Cochrane, T., \& Narayan, V. (2017). Key Themes in Mobile Learning: Prospects for LearnerGenerated Learning Through AR and VR. Australasian Journal of Educational Technology, 33. 
Attewell, J., Savill-Smith, C., \& Douch, R. (2009). The impact of mobile learning: Examining what itmeans for teaching and learning. Retrieved from London: http://www.molenet.org.uk/news/article-8148.aspx

Bannan, B., Cook, J., \& Pachler, N. (2015). Reconceptualizing design research in the age of mobile learning. Interactive Learning Environments, 24(5). doi:10.1080/10494820.2015.1018911

Biggs, J. (2003). Teaching for Quality Learning at University (2nd ed.). Buckingham: The Society for Research into Higher Education.

Brannigan, R., Walsh, K., Graham, S., \& Cochrane, T. (2015). Performance and Mobile Technology. In S. Frielick (Ed.), LTDF 2014 ebook (pp. 91-92). Auckland University of Technology: Centre for Learning And Teaching.

Cochrane, T. (2013). A summary and critique of mlearning research and practice. In Z. Berge \& L. Muilenburg (Eds.), Handbook of mobile learning (Vol. (Awarded the "2014 Association for Educational Communications and Technology (AECT) Division of Distance Learning (DDL) Distance Education Book Award”) (pp. 24-34). New York: Routledge.

Cochrane, T. (2014). Critical success factors for transforming pedagogy with mobile Web 2.0. British Journal of Educational Technology, 45(1), 65-82. doi:10.1111/j.1467-8535.2012.01384.x

Cochrane, T., Black, B., Lee, M., Narayan, V., \& Verswijvelen, M. (2012). Rethinking e-learning support strategies. The International Journal for Academic Development, 18(3), 276-293. doi:10.1080/13 60144X.2012.733884

Cochrane, T., Frielick, S., Narayan, V., Oldfield, J., Moyle, A., \& Bigwood, K. (2015, November 29 - December 2). \#NPF14LMD Learners and Mobile Devices: Sharing Practice. Paper presented at the Globally connected, digitally enabled, the 32nd Ascilite Conference, Curtin University, Perth.

Cochrane, T., \& Munn, J. (2016, June 27-30). EDR and Design Thinking: Enabling Creative Pedagogies. Paper presented at the EdMedia: World Conference on Educational Media and Technology 2016, Vancouver, Canada.

Cochrane, T., Munn, J., \& Antonczak, L. (2013, November 20-22). Design thinking for mlearning: Herding a flock of MOAs. Paper presented at the 3rd Mobile Creativity and Innovation Symposium, AUT University, Auckland, New Zealand.

Cochrane, T., \& Narayan, V. (2012). DeFrosting Professional Development: Reconceptualising Teaching Using Social Learning Technologies. Research in Learning Technology, 19(Suppl. 1), 158-169. doi:10.3402/rlt.v19s1/7796

Cochrane, T., \& Narayan, V. (2016). Evaluating a Professional Development cMOOC: MOSOMELT. In S. Barker, S. Dawson, A. Pardo, \& C. Colvin (Eds.), Show Me The Learning. Proceedings ASCILITE 2016 Adelaide (pp. 139-150). University of South Australia, Adelaide, Australia: Ascilite.

Cochrane, T., Narayan, V., \& Antonczak, L. (2015, November 19). Mobile Learning, Altmetrics, and SOTEL. Paper presented at the 5th Mobile Creativity and Mobile Innovation Symposium, RMIT University, Melbourne, Australia. 
Cochrane, T., Narayan, V., Antonczak, L., \& Burcio-Martin, V. (2016, April 19-20). Modelling Open Practices in Professional Development: Creating a culture of open social scholarship. Paper presented at the The 7th Open Educational Resources Conference, OER 16: Open Culture, University of Edinburgh, UK.

Cochrane, T., Narayan, V., Brannigan, R., Frenchman, K., Nicholson, E., Rutherford, S., . . Neill, C. (2014). \#NPF14LMD AUT University Case Studies. Paper presented at the Rhetoric and Reality, proceedings of the 31st Ascilite Conference, Otago Polytechnic, Dunedin. Poster retrieved from http:// ascilite2014.otago.ac.nz/posters/

Cochrane, T., Narayan, V., \& Burcio-Martin, V. (2015). Designing a cMOOC for Lecturer Professional Development in the 21st Century. In J. Keengwe \& G. Onchwari (Eds.), Handbook of Research on Active Learning and the Flipped Classroom Model in the Digital Age (pp. 378-396). Hershey, PA: IGI Global.

Cochrane, T., Narayan, V., Burcio-Martin, V., Lees, A., \& Diesfeld, K. (2015, November 29 - December 2). Designing an authentic professional development cMOOC. Paper presented at the 32nd Ascilite Conference Globally connected, digitally enabled, Curtin University, Perth.

Cochrane, T., Narayan, V., \& Oldfield, J. (2013). iPadagogy: Appropriating the iPad within pedagogical contexts. International Journal of Mobile Learning and Organisation, 7(1), 48-65. doi:10.1504/ IJMLO.2013.051573

Cochrane, T., Narayan, V., \& Oldfield, J. (2015). Emerging technologies in New Zealand: A pedagogical framework for mobile social media. In V. Bozalek, D. Ngambi, A. Amory, J. Hardman, D. Wood, \& J. Herrington (Eds.), Activity theory, authentic learning, and emerging technologies: Southern perspectives (pp. 126-143). New York: Routledge.

Cook, J. (2009). Phases of mobile learning. In Joint European Summer School on Technology Enhanced Learning, May 30 - June 6. Retrieved from http://www.slideshare.net/johnnigelcook/cook-phases-ofmobile-learning

Cook, J., Pachler, N., \& Bachmair, B. (2013). Using social network sites and mobile technology to scaffold equity of access to cultural resources. In M. Repetto \& G. Trentin (Eds.), Using Network and Mobile Technology To Bridge Formal and Informal Learning (10 ed., pp. 31-56). Oxford: Chandos Publishing. doi:10.1016/B978-1-84334-699-9.50002-1

Cook, J., \& Santos, P. (2016). Three Phases of Mobile Learning State of the Art and Case of Mobile Help Seeking Tool for the Health Care Sector. In D. Churchill, J. Lu, T. K. F. Chiu, \& B. Fox (Eds.), Mobile Learning Design (pp. 315-333). Springer Singapore. doi:10.1007/978-981-10-0027-0_19

Cormier, D. (2008). Rhizomatic education: Community as curriculum. Innovate, 4(5). Retrieved from http://davecormier.com/edblog/2008/2006/2003/rhizomatic-education-community-as-curriculum/

Dahlstrom, E., Brooks, C., Grajek, S., \& Reeves, J. (2015). ECAR Study of Undergraduate Students and Information Technology, 2015. Retrieved from http://www.educause.edu/library/resources/2015student-and-faculty-technology-research-studies

Frielick, S., Cochrane, T., Aguayo, C., Narayan, V., O’Carrol, D., Smith, N., . . Wyse, P. (2014, April 12). Learners and mobile devices (\#NPF14LMD): A framework for enhanced learning and institutional change. Retrieved from https://akoaotearoa.ac.nz/learner-mobile-devices 
Frielick, S., Cochrane, T., Narayan, V., Moyle, A., \& Oldfield, J. (2015, November 29 - December 2). \#NPF14LMD Learners and Mobile Devices: Symposium. Paper presented at the Globally connected, digitally enabled, the 32nd Ascilite Conference, Curtin University, Perth.

Frielick, S., \& Whitehead, E. (2017). Learners and Mobile Devices: Learner Survey Conclusions. Retrieved from http://mobilelearners.nz/learners-and-mobile-devices/conclusion?path=learner-survey

Hase, S., \& Kenyon, C. (2007). Heutagogy: A child of complexity theory. Complicity: an International Journal of Complexity and Education, 4(1), 111-118.

Hawksey, M. (2011). Twitter: How to archive event hashtags and create an interactive visualization of the conversation. Blog Retrieved from http://mashe.hawksey.info/2011/11/twitter-how-to-archive-eventhashtags-and-visualize-conversation/

Head, G., \& Dakers, J. (2005). Verillon's trio and Wenger's community: Learning in technology education. International Journal of Technologyand Design Education, 15(1), 33-46. doi:10.100710798-004-6194-3

Heap, R., Neveldsen, P., Bigwood, K., Bruce, T., Moyle, A., \& Leichtweis, S. (2015). Four voices on Learners and Mobile Devices in Teacher Education. Paper presented at the ISATT 2015: 17th Biennial Conference of Teachers and Teaching, University of Auckland. Retrieved from http://isatt2015.com/

Herrington, J., Reeves, T., \& Oliver, R. (2009). A guide to authentic e-learning. London, New York: Routledge.

International Telecommunication Union. (2014). The World in 2014: ICT facts and figures2014(April). Retrieved from http://www.itu.int/en/ITU-D/Statistics/Documents/facts/ICTFactsFigures2014-e.pdf

Jameson, J. (2011). Growing the eLIDA CAMEL Community of Practice Case Study. In Handbook of Research on Communities of Practice for Organizational Management and Networking: Methodologies for Competitive Advantage (pp. 443-455). Hershey, PA: IGI Global.

Jameson, J., Ferrell, G., Kelly, J., Walker, S., \& Ryan, M. (2006). Building trust and shared knowledge in communities of e-learning practice: Collaborative leadership in the JISC eLISA and CAMEL lifelong learning projects. British Journal of Educational Technology, 37(6), 949-967. doi:10.1111/j.14678535.2006.00669.x

Kaufman, J. C., \& Sternberg, R. J. (2007). Creativity. Change: The Magazine of Higher Learning, 39(4), 55-60. doi:10.3200/CHNG.39.4.55-C4

Kenobi, B., \& Cochrane, T. (2015). Innovative Pedagogy in Game Design. In S. Frielick (Ed.), LTDF 2014 ebook (pp. 79-81). Auckland University of Technology: Centre for Learning And Teaching.

Kukulska-Hulme, A. (2010). Mobile learning as a catalyst for change. Open Learning: The Journal of Open and Distance Learning, 25(3), 181-185. doi:10.1080/02680513.2010.511945

Kukulska-Hulme, A., Sharples, M., Milrad, M., Arnedillo-Sanchez, I., \& Vavoula, G. (2009). Innovation in mobile learning: A european perspective. International Journal of Mobile and Blended Learning, 1(1), 13-35. doi:10.4018/jmbl.2009010102 
Laurillard, D. (2001). Rethinking University Teaching: a framework for the effective use of educational technology (2nd ed.). London: Routledge.

Laurillard, D. (2007). Pedagogcal forms of mobile learning: framing research questions. In N.Pachler(Ed.), Mobile learning: towards a research agenda (pp. 33-54). London: WLE Centre, Institute of Education.

Laurillard, D. (2012). Teaching as a design science: Building pedagogical patterns for learning and technology. New York: Routledge.

Learning and Skills Network. (2009). MoleNET2009(30 July), MoleNET web site. Retrieved from http:// www.molenet.org.uk/about/

Lindsay, L. (2015). Transformation of teacher practice using mobile technology with one-to-one classes: M-learning pedagogical approaches. British Journal of Educational Technology, 47(5), 883-892. doi:10.1111/bjet.12265

Luckin, R. (2008). The learner centric ecology of resources: A framework for using technology to scaffold learning. Computers \& Education, 50(2), 449-462. doi:10.1016/j.compedu.2007.09.018

Luckin, R., Clark, W., Garnett, F., Whitworth, A., Akass, J., Cook, J., \& Robertson, J. (2010). LearnerGenerated Contexts: A Framework to Support the Effective Use of Technology for Learning. In M. Lee \& C. McLoughlin (Eds.), Web 2.0-Based E-Learning: Applying Social Informatics for Tertiary Teaching (pp. 70-84). Hershey, PA: IGI Global. doi:10.4018/978-1-60566-294-7.ch004

\#NPF14LMD. (2017a). Learners and Mobile Devices: Appendix D Research Outputs. Retrieved from http://mobilelearners.nz/learners-and-mobile-devices/appendix-d-research-outputs?path=appendices

\#NPF14LMD. (2017b). Learners and Mobile Devices: Conclusion. Retrieved from http://mobilelearners. nz/learners-and-mobile-devices/concluding-remarks

\#NPF14LMD. (2017c). Learners and Mobile Devices: Interactive Report. Retrieved from http://mobilelearners.nz/learners-and-mobile-devices/index

\#NPF14LMD. (2017d). Learners and Mobile Devices: Practitioner Reflections. Retrieved from http:// mobilelearners.nz/learners-and-mobile-devices/practitioner-reflections

Pachler, N., Bachmair, B., \& Cook, J. (2010). Mobile learning: Structures, agency, practices. London: Springer. doi:10.1007/978-1-4419-0585-7

Parsons, D. (Ed.). (2013). Innovations in Mobile Educational Technologies and Applications. Hershey, PA: IGI Global. doi:10.4018/978-1-4666-2139-8

Parsons, D. (2014). A Mobile Learning Overview by Timeline and Mind Map. International Journal of Mobile and Blended Learning, 6(4), 1-21. doi:10.4018/ijmbl.2014100101

Puentedura, R. (2006). Transformation, Technology, and Education. Retrieved from http://hippasus. com/resources/tte/puentedura_tte.pdf

Punie, Y. (2013). Up-Scaling Creative Classrooms in Europe (SCALE CCR). Retrieved from http://is.jrc. ec.europa.eu/pages/EAP/SCALECCR.html 
Reeves, T. C. (2015). Educational design research: Signs of progress. Australasian Journal of Educational Technology, 31(5), 613-620. doi:10.14742/ajet.2902

Sharples, M. (2013). Mobile learning: Research, practice and challenges. Distance Education in China, $3(5), 5-11$.

Sharples, M., Taylor, J., \& Vavoula, G. (2007). A Theory of Learning for the Mobile Age. In K. Littleton \& P. Light (Eds.), The Sage Handbook of E-learning Research (pp. 221-247). London: Sage. doi:10.4135/9781848607859.n10

Siemens, G. (2004). Connectivism: A Learning Theory for the Digital Age. eLearnspace, (12 December). Retrieved from http://www.elearnspace.org/Articles/connectivism.htm

Sternberg, R. J., Kaufman, J. C., \& Pretz, J. E. (2002). The creativity conundrum: A propulsion model of kinds of creative contributions. Philadelphia: Psychology Press.

Traxler, J. (2010). Will student devices deliver innovation, inclusion, and transformation? Journal of the Research Center for Educational Technology, 6(1), 3-15.

Traxler, J. (2016a). Inclusion in an age of mobility. Research in Learning Technology, 24(1), 31372. doi:10.3402/rlt.v24.31372

Traxler, J. (2016b). What killed the mobile learning dream? Jisc Inform. Retrieved from https://www. jisc.ac.uk/inform-feature/what-killed-the-mobile-learning-dream-26-feb-2016?

Vygotsky, L. (1978). Mind in Society. Cambridge, MA: Harvard University Press.

Wenger, E. (1998). Communities of Practice: Learning, Meaning, and Identity. Cambridge: Cambridge University Press. doi:10.1017/CBO9780511803932

Wenger, E., McDermott, R., \& Snyder, W. (2002). Cultivating communities of practice: a guide to managing knowledge. Boston: Harvard Business School Press.

Wenger, E., White, N., \& Smith, J. (2009). Digital Habitats: stewarding technology for communities. Portland, OR: CPsquare.

Wenger, E., White, N., Smith, J., \& Rowe, K. (2005). Technology for Communities. In L. Langelier (Ed.), Working, Learning and Collaborating in a Network: Guide to the implementation and leadership of intentional communities of practice (pp. 71-94). Quebec City: CEFIRO.

This work was previously published in the International Journal of Mobile and Blended Learning (IJMBL), 10(4); pages 73-92, copyright year 2018 by IGI Publishing (an imprint of IGI Global). 


\section{University Library}

\section{- M M I N E R VA A gateway to Melbourne's research publications}

Minerva Access is the Institutional Repository of The University of Melbourne

Author/s:

Cochrane, T;Vickel, N

Title:

Nurturing Collaborative Networks of Mobile Learning Researchers and Practitioners

Date:

2021

Citation:

Cochrane, T. \& Vickel, N. (2021). Nurturing Collaborative Networks of Mobile Learning Researchers and Practitioners. Information Resources Management Association, (Ed.). Research Anthology on Facilitating New Educational Practices Through Communities of Learning, (1), pp.325-346. IGI Global.

Persistent Link:

http://hdl.handle.net/11343/267518 